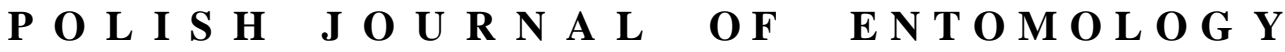

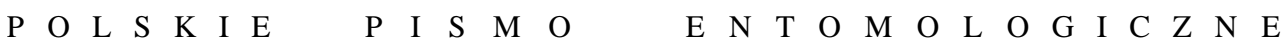

VOL. 85: 191-223

Lublin

30 June 2016

DOI: $10.1515 /$ pjen-2016-0011

\section{Tortricidae (Lepidoptera) from the Fiji Islands, part 2}

\author{
JÓZEF RAZOWSKI* \\ Institute of Systematics and Evolution of Animals, Polish Academy of Sciences, \\ Sławkowska 17, 31-016 Kraków, Poland
}

\begin{abstract}
Forty-seven species are discussed. One new genus (Daedaluncus gen. n.) and 15 new species (Adoxophyes vitilevu sp. n., Adoxophyes niuwudi sp. n., Atriscripta strigana sp. n., Helictophanes saccifera sp. n., Loboschiza oxybela sp. n., Epinotia prepuncus sp. n., Daedaluncus fijiensis sp. n., Coenobiodes vitiae sp. n., Tritopterna rakiraki sp. n., Spilosoma oligospina sp. n., Strepsicrates rotundata sp. n., Eccoptocera platamon sp. n., Herpystis sunia sp. n., Herpystis spinoa sp. n., Cryptophlebia ferrugulla sp. n.) are described and illustrated.
\end{abstract}

KEY WORDS: Lepidoptera, Tortricidae, new taxa, faunistics, Fiji.

\section{INTRODUCTION}

This paper constitutes the second part of my studies on the Tortricidae of the Fiji Islands. In the first part (RAZOWSKI 2016) I listed a total of twenty-five species and described fifteen as new. Additional data are provided for twelve species recorded by RAZOWSKI (2016) and five species described by MEYRICK (listed in the same paper) (Aphrozestis scoriopa MEYRICK, 1931, Arothrophora fijigena RAZOWSKI, 2009, Pteridoporthis euryloxa MEYRICK, 1937, Strepsicrates glaucothoe MEYRICK, 1927, Acanthoclita defensa (MEYRICK, 1922) and Proactenis leucocharis (MEYRICK, 1933)).

Based on the material examined, the tortricid fauna of Fiji is most similar to that of Australia, chiefly Queensland, with 11 species in common: Cryptaspasma sordida (TURNER, 1945), Bactra blepharopis MEYRICK, 1911, B. optanias MEYRICK, 1911, Procoronis swinhoeiana (WALSINGHAM, 1890), Thaumatotibia zophophanes (TURNER, 1946),

\footnotetext{
*Corresponding author: Razowski@isez.pan.krakow.pl
} 
Acanthoclita trichograpta (MEYRICK, 1911), Microsarotis sanderyi KOMAI \& HORAK, 2006, Atriscripta arithmetica MEYRICK, 1921, Noduliferola neothela (TURNER, 1916), Strepsicrates glaucothoe, Acanthoclita defensa. Twelve species documented from Fiji are widely distributed, recorded from the Oriental region: Adoxophyes fasciculana (WALKER, 1866), Dudua aprobola WALKER, 1864, Semiotes halantha (MEYRICK, 1909), Procoronis swinhoeiana, Herpystostena sicaria (DIAKONOFF, 1982), Bactra angulata DiAKONOFF, 1956, Statheropis leucaspis (MEYRICK, 1902), Helictophanes prospera (MEYRICK, 1909), Periphoeba adluminana BRADLEY, 1957, Crocidesema lantana BUSCK, 1910. Two species are nearly cosmopolitan: Bactra venosana (ZELLER, 1847), Crocidosema plebejana ZELLER, 1847. Several species found in Fiji are known from New Caledonia (e.g. Diakonoffiana argynnis RAzOwSKI, MS), New Hebrides (e.g. Lobesia orthomorpha (MEYRICK, 1928), Strepsicrates poliophora BRADLEY, 1862, Collogenes dascia (BRADLEY, 1862)), the Marquesas (e.g. Tritopterna eocnephaea (MEYRICK, 1935), Thaumatotibia chaomorpha (MEYRICK, 1928)) or Micronesia (e.g. Cryptophlebia amblyopa CLARKE, 1976). The distribution of the majority of them is still insufficiently known, however.

\section{Acknowledgements}

The author thanks Mr Kevin R. TUCK, London, who kindly selected and loaned this valuable material, and Mr Witold ZAJDA, Kraków, who dissected and photographed the specimens and arranged the plates.

\section{MATERIALS}

The paper is based on specimens housed in the Natural History Museum London (formerly the British Museum (Natural History)) collected chiefly by G.S. RoBINSON (IX-1973, III-XI. 1974 and I-III and IX 1975) and H.S. and G.S. RoBINSON (VIII. 1968 and 1969), but also by H.S. Evans (VI. 1956), R.A. LeVer (1941), P.A. MAdDISON (I, IX. 1975), and H.W. SIMMONDS (VI, IX. 1954 and 1955).

\section{Abbreviation \\ GS - genitalia slide.}




\title{
RESULTS
}

Schoenotenini

\section{Aphrozestis scoriopa MEYRICK, 1931}

(Figs 1, 2)

\author{
Material examined \\ One male from Viti Levu Nandarivatu, 20-26. III. 1974, H.S. RoBINSON; GS 33898.
}

\section{Description}

Male genitalia (Figs 1, 2). Apodemes from pedunculi very large, sack-shaped; uncus uniformly broad, moderately long; gnathos arm broad; terminal plate broad to beyond middle, then tapering terminad, bifid apically; socius densely bristled in posterior half; vinculum broad, weakly concave terminally; valva elongate, tapering terminad, weakly extending ventrocaudally, densely hairy in posterior half dorsally; sacculus slender, simple; aedeagus slender extending dorsoterminally; processes from zone long, slender, in the types mentioned below curved (the differences are probably an artifact of slide mounting).

\section{Remarks}

A. scoriopa was described from Lautoka, Fiji, and the male holotype was illustrated by ClARKE (1958). In the illustrated male genitalia the distal part of the valva is somewhat damaged, hence the above description and figure of the newly examined specimen is provided. BRADLEY (1962) described its synonym, Schoenotenes elaphrodes from Aneityum, New Hebrides.

Undescribed tribe

\section{Arotrophora fijigena RAZOWSKI, 2009}

\section{Material examined}

One female from Vanua Levu, Forest Area Niuvudi, Navonu, 3-6. IX. 1975, P.A. MADDISON, M.V. LIGHT; GS 33870.

\section{Remarks}

Known from one male collected in Viti Levu, Suva. 


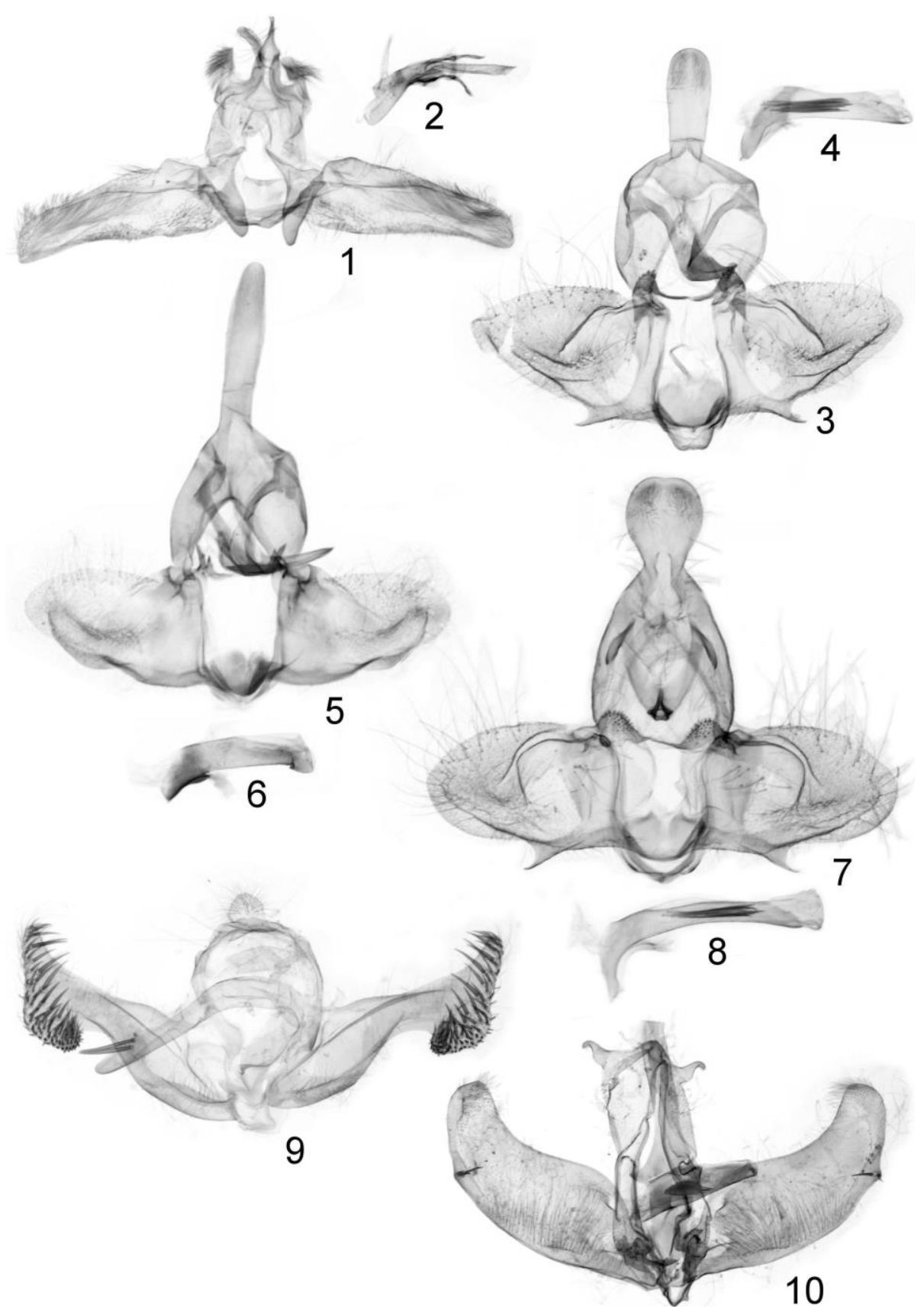

Figs 1-10. Male genitalia. 1, 2 - Aphrozestis scoriopa, Fiji: Viti Levu Nandarivatu; 3, 4 - Adoxophyes mixtior, Fiji: Viti Levu Nandarivatu; 5, 6-Adoxophyes vitilevu sp. n., holotype; 9 - Collogenes dascia, Fiji: Viti Levu Nandarivatu; 10 - Atriscripta strigata sp. n., holotype. 
Archipini

Nairips mastrus RAZOWSKI, 2016

\section{Material examined}

Seven specimens from Viti Levu Nandarivatu, 3-5. IX. 1974, G.S. RoBINSON and IX. 1955, H.W. SIMMONDS; GS 23186, 23187, 3347, 3348, 33974.

\section{Variation}

Forewing ground colour varies from pale brown to white, markings more or less distinct, occasionally confluent, brown to rust brown.

\section{Pteridoporthis ?euryloxa MEYRICK, 1933}

\section{Material examined}

One male from Viti Levu, VII. 1974, G.S. RoBINSON; GS 33922.

\section{Remarks}

This species was described from Vunidawa, Fiji; the "type" [lectotype] was illustrated by CLARKE (1958). RAZOWSKI (2016) recorded it from Fiji. The specimen examined is almost unicolorous brownish with indistinct brown forewing markings.

\section{Adoxophyes mixtior RAZOWSKI, 2016}

(Figs 3, 4, 23, 30, 31)

\section{Material examined}

Five males and one female from Viti Levu Nandarivatu, 3-5. IX. 1974, G.S. RoBINSON; GS $33915,33916,33918$.

\section{Description}

Female. Wing span $24 \mathrm{~mm}$. Forewing rather uniformly broad throughout, slenderer than in male. Ground colour cream. Markings well developed, brownish with some dark brown marks.

Female genitalia (Fig. 23). Sterigma small with short anteostial part and slender lateral arms; antrum sclerite very weak; ductus bursae long; signum absent; group of minute spines in corpus bursae at base of ductus bursae. 


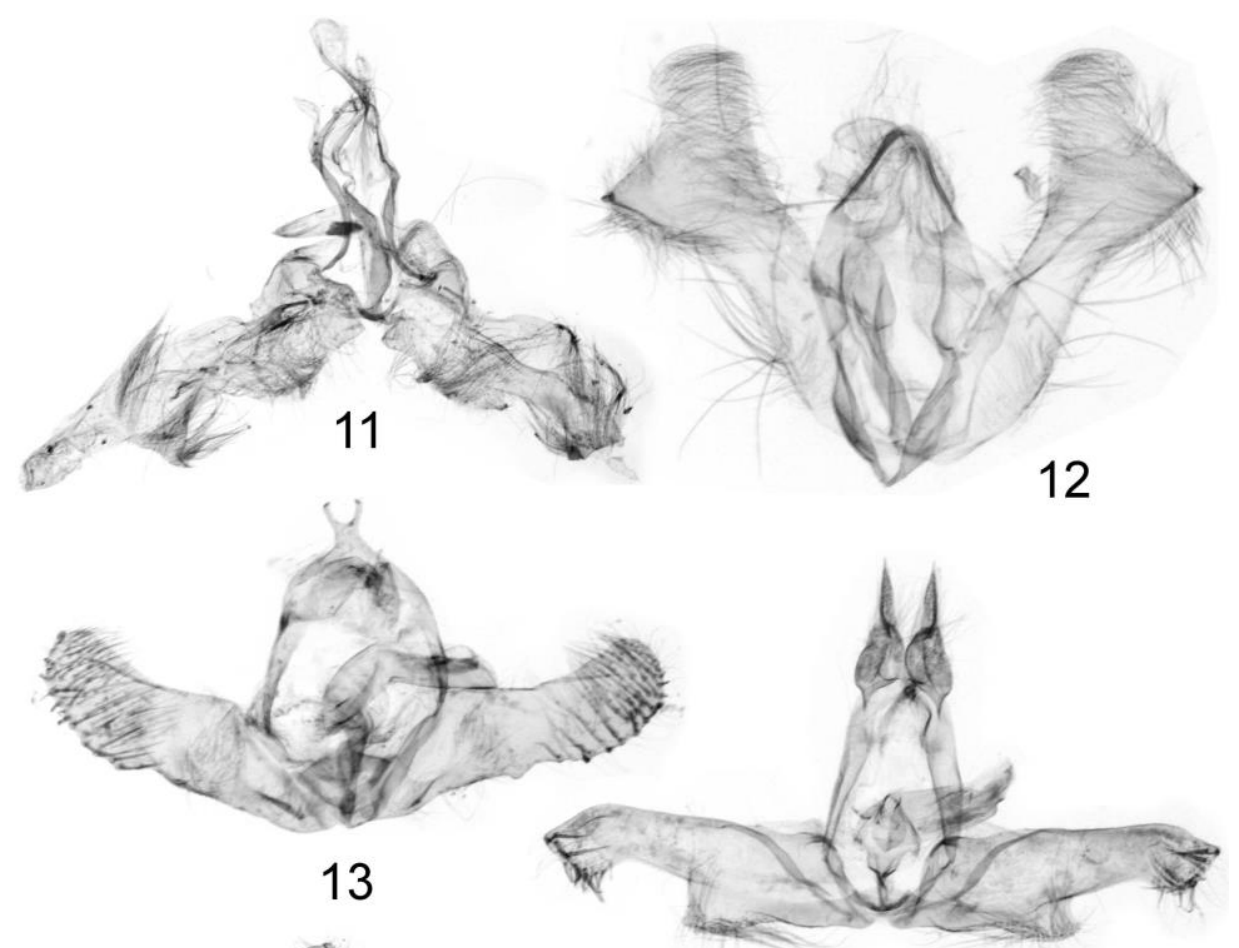

14

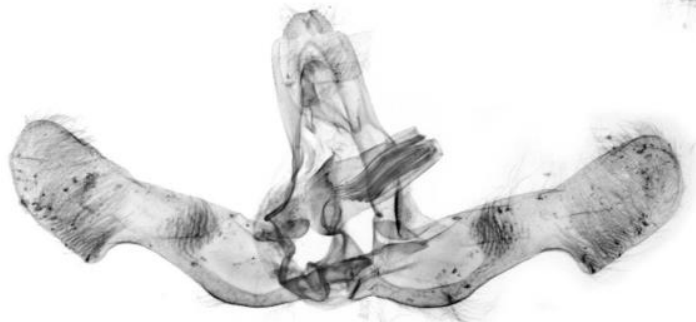

15
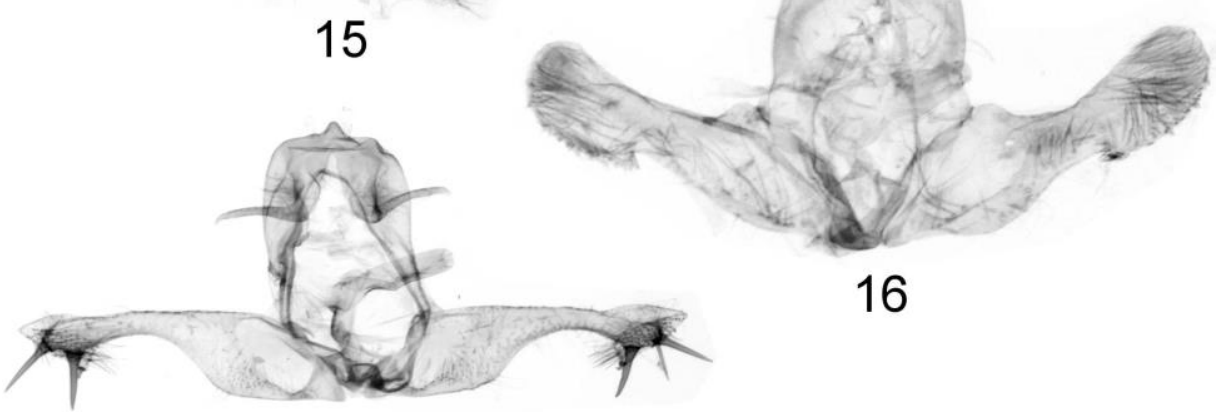

16

17

Figs 11-17. Male genitalia. 11 - Helictophanes saccifera sp. n., holotype; 12 - Loboschiza oxybela sp. n., holotype; 13 - Epinotia prepuncus sp. n., holotype; 14 - Daedaluncus fijiensis sp. n., holotype; 15 - Coenobiodes vitiae sp. n., holotype; 16 - Tritopterna rakiraki sp. n., holotype; Spilonota oligospina sp. n., holotype. 


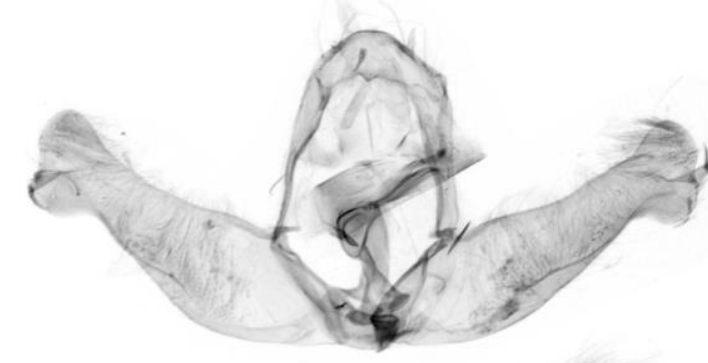

18
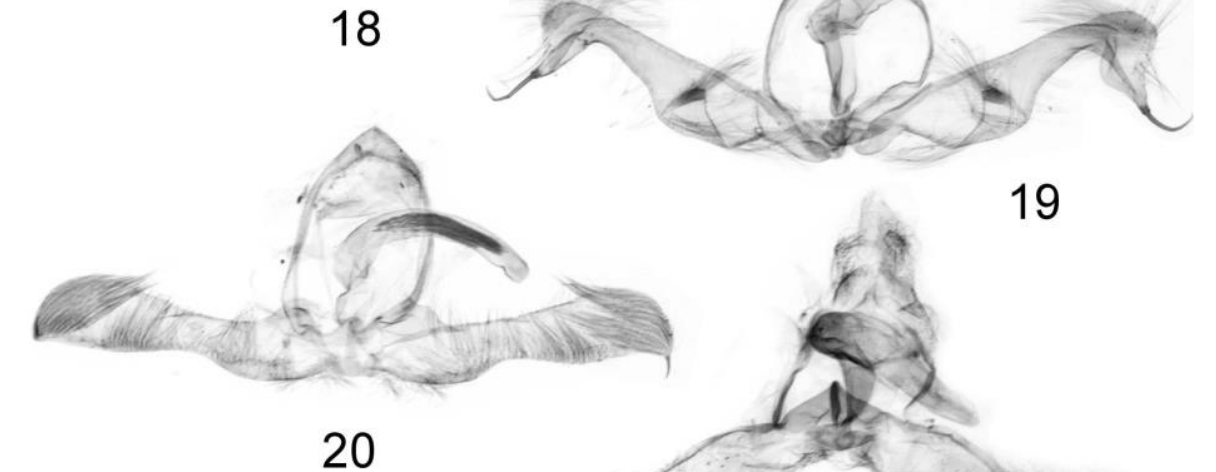

19

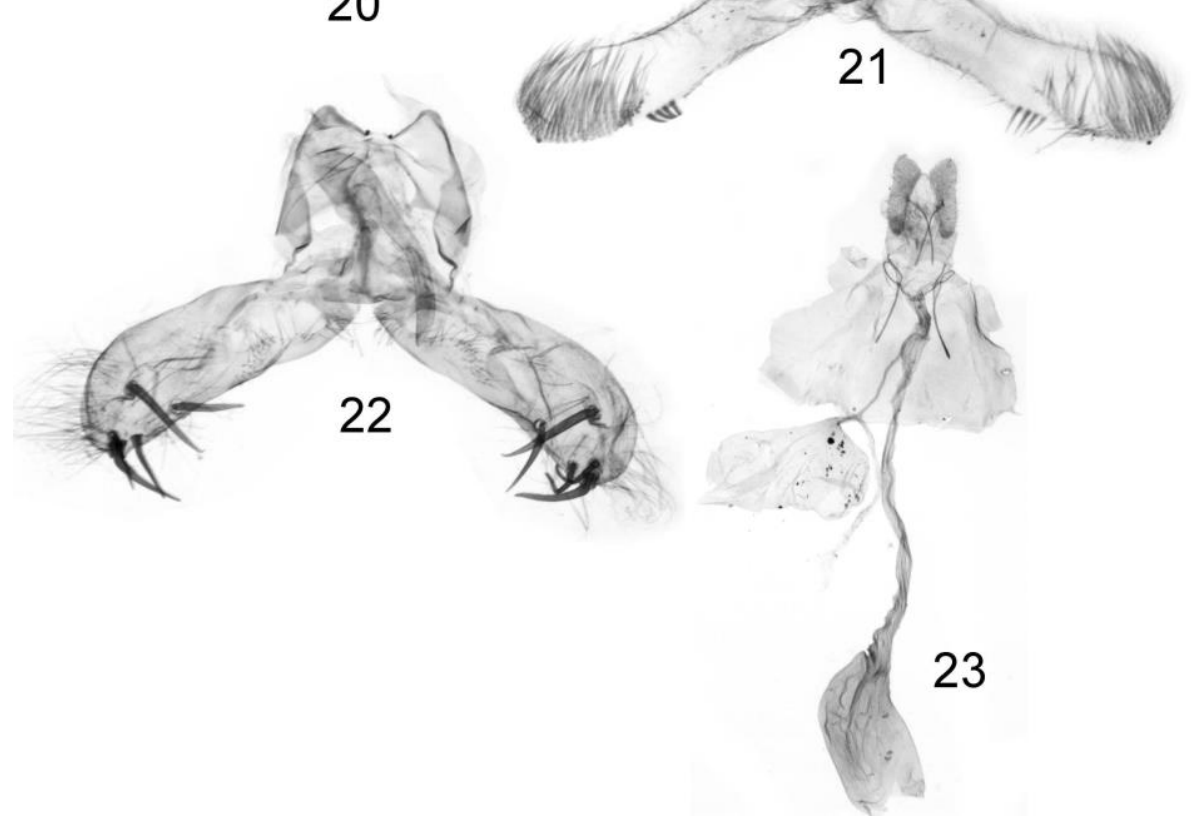

Figs 18-23. Male and female genitalia. 18 - Strepsicrates rotundata sp. n., holotype; 19 - Eccoptocera platamon sp. n., holotype; 20 - Herpystis sunia sp. n., holotype; 21 - Herpystis spinoa sp. n., holotype; 22 - Crytophlebia ferrugula sp. n., holotype; 23 - Adoxophyes mixtior, GS 33918. 

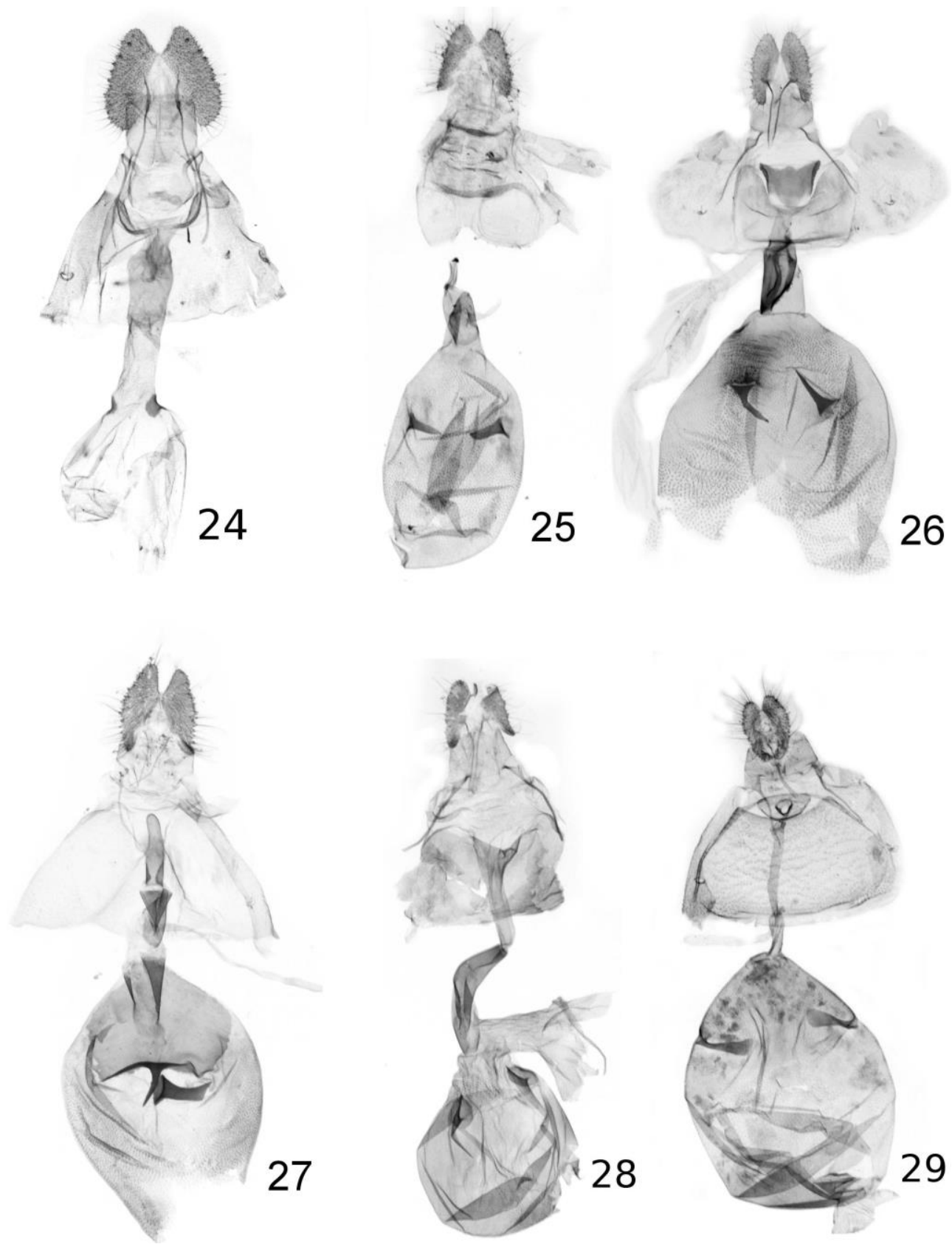

Figs 24-29. Female genitalia. 24 - Collogenes dascia, GS 33911; 25 - Daedaluncus fijiensis sp. n., paratype; 26 - Coenobiodes vitiae sp. n., holotype; 27 - Eccoptocera platamon sp. n., holotype; 28 - Herpystis sunia sp. n., paratype; 29 - Acanthoclita defensa, GS 33904. 

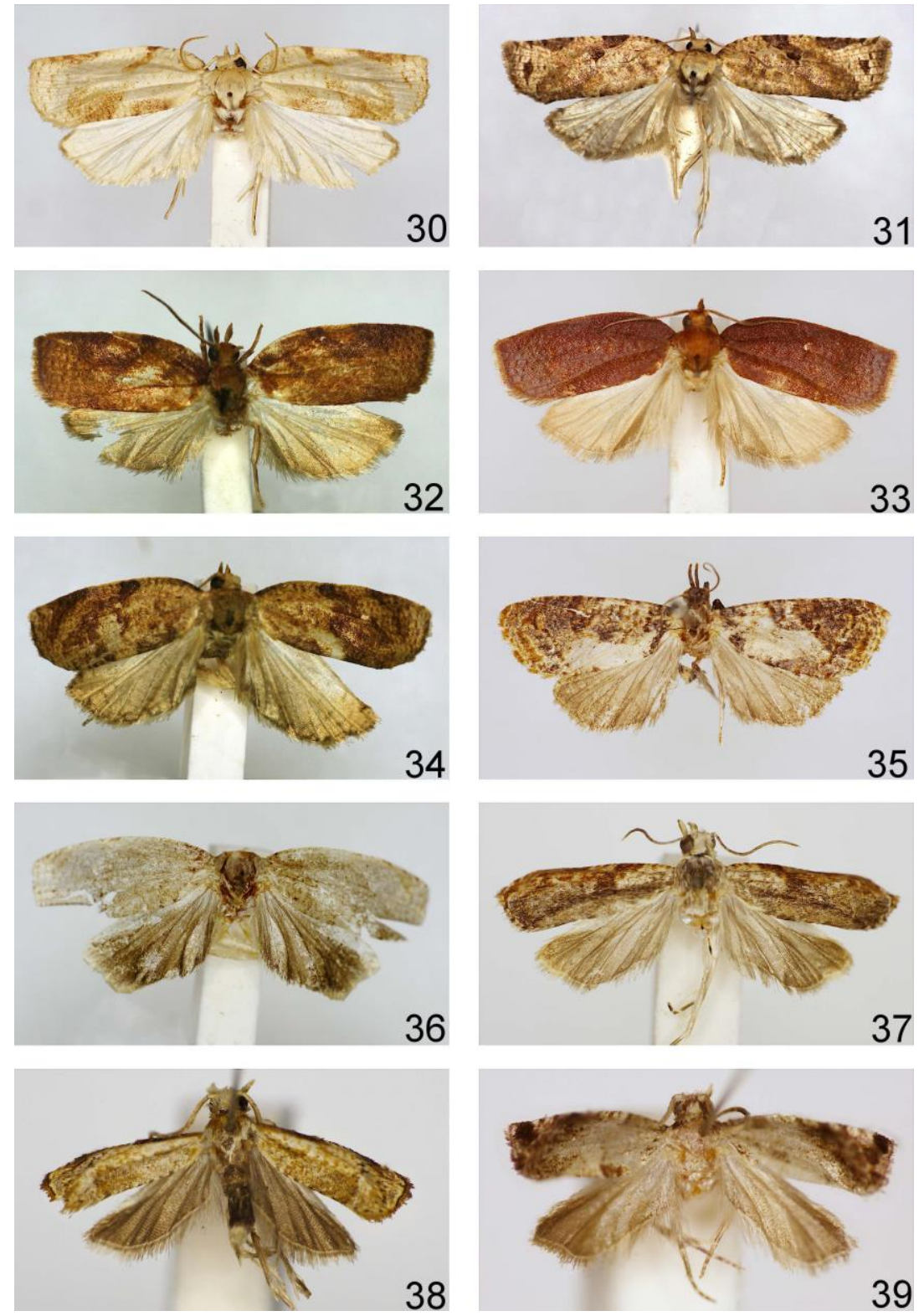

Figs 30-39. Adults. 30 - Adoxophyes mixtior, male, GS 33915; 31 - Adoxophyes mixtior, female, GS 33918; 32 - Adoxophyes vitilevu sp. n., holotype male; 33 - Adoxophyes vitilevu sp. n., paratype female holotype; 34 - Adoxophyes niuvudi sp. n., GS holotype; 35 - Collogenes dascia GS 33911; 36 - i-Atriscripta strigata sp. n., holotype; 37 - Helictophanes saccifera sp. n., holotype; 38 - Loboschiza oxybela sp. n., holotype; 39 - Epinotia prepuncus sp. n., paratype. 


\section{Remarks}

The species was described from a single male collected in Nairayawa. A male in better condition and the previously unknown female are illustrated here. The male genitalia of the specimen from Viti Levu are shown in Figs. 3, 4.

\section{Adoxophyes vitilevu sp. $\mathrm{n}$.}

(Figs 5, 6, 32, 33)

\section{Diagnosis}

A. vitilevu is similar to Dichelopa castanopis ClARKE, 1986 from Uapou, Marquesas from which vitilevu differs in its long, slender uncus, shorter aedeagus and cream hindwing.

\section{Description}

Wing span $20 \mathrm{~mm}$. Head and thorax ferruginous. Forewing not expanding terminally; termen not oblique. Ground colour cream ferruginous, darkening towards costa, densely spotted rust. Markings rust brown, preserved along costa, consisting of remnants of basal blotch, median fascia and subapical spot. Cilia darker than ground colour. Hindwing cream tinged brownish on peripheries; cilia similar in colour.

Variation. In paratype, head, thorax, and forewing dark rust brown, in distal third more glossy violet; strigulation pale rust; cilia concolorous with latter.

Male genitalia (Figs 5, 6). Uncus long, slender, slightly broadening medially; arm of gnathos simple, terminal plate long; valva elongate-oval; sacculus long, convex, slightly broadening posteriorly; basal lobes of transtilla weak with a few long spines; aedeagus uniformly broad in median part, expanding ventroterminally where small proximal prominence present.

Female unknown.

\section{Material examined}

Holotype male: "Fiji: Viti Levu Nandarivatu, IX. 1955, H.W. SIMMONDS"; GS 33912. Paratype male, same label, but dated 3-5. IX. 1974, G.S. ROBINSON, GS 33913.

\section{Etymology}

The specific epithet refers to the type locality. 


\section{Adoxophyes niuvudi sp. $\mathbf{n}$.}

(Figs 7, 8, 34)

\section{Diagnosis}

A. niuvudi is related to A. mixtior, but $A$. niuvudi has a longer, slenderer uncus and slenderer basal lobes of the transtilla. In facies, $A$. niuvudi does not differ from A. mixtior.

\section{Description}

Wing span $26 \mathrm{~mm}$. Head brownish cream, labial palpus and thorax more rust brown. Forewing not expanding terminally; termen not oblique to middle. Ground colour brownish, strigulated brown. Markings rust brown with paler parts consisting of dorsobasal suffusion, median fascia and subapical blotch extending to before middle of termen. Cilia concolorous with markings. Hindwing brownish yellow, cream towards base, mixed brown in anal area, with some brownish stripes terminally; cilia cream.

Variation. Paratype forewing ground colour creamish, suffusions pale rust and brownish; markings well preserved at costa, brownish. Hindwing creamer than in holotype.

Male genitalia (Figs 7, 8). Uncus broad, narrowing basally; socius very small; gnathos simple; valva oval; sacculus with distinct arched process near middle; basal lobes of transtilla broad, minutely thorny; aedeagus long, slender, protruding ventroterminally; cornuti moderately long.

Female unknown.

\section{Material examined}

Holotype male: "Fiji: Vanua Levu, Forest Area Niuvudi, 6-7. IX. 1975, P.A. MADDISON"; GS 23196. Paratype, same label, GS 33917.

\section{Etymology}

The specific name is based on the name of the type locality: Forest Area Niuvudi.

Adoxophyeas lamii RAZOWSKI, 2016

\section{Material}

One female from Viti Levu Suva Creek, 29. VII. 1974, G.S. RoBINSON; GS 33921.

\section{Remarks}

Described from the vicinity of Lami; the male remains unknown. 


\section{Dichelopa litota RAZOWSKI, 2016}

\section{Material examined}

One male from Viti Levu Suva, 29. VII. 1974, G.S. RoBINSON; GS 33923.

\section{Remarks}

This species was described from one male from Fiji. The female remains unknown.

Microcorsini

Cryptaspasma sordida (TURNER, 1945)

\section{Material}

One female from Viti Levu Nandarivatu, I. 1955, H.W. SIMMONDS; GS 33909.

\section{Remarks}

C. sordida was described from Queensland, Australia.

\section{Collogenes dascia (BRADLEY, 1962)}

(Figs 9, 24, 35)

\section{Material examined}

Eight specimens from Viti Levu Nandarivatu, 15-17. VIII. 1969 and 27-30.IX. 1968, H.S. \& G.S. Robinson; Nandarivatu, 28. VI. 1968, H.S. RobINSON; Suva, 20. X. 1969, H.S. \& G.S. Robinson; Vunidawa, 12.IX. 1934, H. PhILlIPS; Fiji, V. 1966, H.S. RoBINSON; 1955, H.W. SimMONDS; Suva 1955, H.W. SimMONDS; Fiji 1966-67, H.S. RoBINSON; GS 15603, 15604 , 33908, 33910, 33911.

\section{Description}

Female genitalia (Fig. 24). Proximal part of sterigma slender, lateral parts somewhat expanding towards middle; posterior part of ductus bursae built of thick membrane, plicate; signa short, posterior. 


\section{Variation}

Ground colour of forewing yellowish brown to brownish; suffusions brown, more or less distinct; pattern brown with dark brown parts; one specimen almost unicolorous brown. Male genitalia (Fig. 9; GS 15605) are illustrated for comparison.

\section{Olethreutini}

\section{Atriscripta strigata sp. n.}

(Figs 10, 36)

\section{Diagnosis}

A. strigata is very closely related to A. arithmetica (MEYRICK, 1921) from Australia and A. decorigera (DIAKONOFF, 1966) from New Guinea. The male genitalia of the three are very similar, in A. strigata the aedeagus is broader, the top of the tegumen produced, and the cornuti less numerous. Externally the species are distinct, as well. A. strigata has a longer, almost uniformly broad forewing and dense broad strigulation, and lacks the ocellar and subcostal strigulae; the hindwing is dark brown with yellowish cream peripheries from apex to anal area, and the termen is distinctly extended at veins M3-CuA1.

\section{Description}

Wing span $22 \mathrm{~mm}$. Head and proximal part of thorax brownish, remaining part of latter brown. Forewing not expanding posteriorly; costa distinctly curved basally, then slightly so, termen oblique beyond end of M3. Ground colour brownish cream, much paler in distal area from mid-costa to tornus; suffusions brown; strigulation brown and rust brown; costal strigulae small, creamish, divisions rust brown. Markings indistinct (remnant of basal blotch and median fascia) brown-grey. Cilia damaged. Hindwing strongly convex at vein M3, brown except for terminal part from apex to vein M3 which is creamish, concolorous with cilia.

Male genitalia (Fig. 10). Tegumen high with elongate top; socius slender, curved terminally; tuba analis long; valva broadest postbasally, convex dorsally; sacculus slightly convex; cucullus fairly broad; pollex small with two spines; aedeagus moderately broad, tapering from beyond middle; cluster of cornuti rather small.

Female unknown.

\section{Material examined}

Holotype male: "Fiji, Forest area, Niuvudi Levu, 6-7. IX. 1975, P.A. MADDISON. M.V. LIGHT"; GS 33871. 


\section{Etymology}

The specific name refers to the strigulation of the forewing; Latin: strigata - strigulated.

\section{Dudua aprobola (MEYRICK, 1886)}

\section{Material examined}

One male labelled Fiji, H.S. RoBINSON, 1966-67; GS 33897.

\section{Remarks}

This species was described from Tonga; it is widely distributed throughout the IndoAustralian region to the South Pacific Islands including the Society Islands north to China, Formosa, and Natal (CLARKE 1976).

\section{Bactra angulata DIAKONOFF, 1956}

\section{Material examined}

Two male and one female from Viti Levu, Suva, VI. 1974, H.S. G.S. RoBINSON. GS 33885-3386.

\section{Remarks}

B. angulata was described from East Borneo; it is known from Java and the Moluccan Islands to the southern Mariana Islands and Micronesia.

\section{Bactra venosana (ZELLER, 1847)}

\section{Material examined}

Three males from Viti Levu, Suva, II. and IX. 1975.

\section{Remarks}

Described from Sicily, the species is known from Asia Minor, East Asia, North Africa and Micronesia. 


\section{Bactra optanias MEYRICK, 1911}

\section{Material examined}

Three males and two females from Viti Levu, Suva, VII and XII. 1974; Viti Levu, Suvasavu, II. 1975, G.S. RoBINSON; and Viti Levu Suva, 5-8. VIII. 1974, G.S. RobINSON. GS $33882,33883,33890$.

\section{Remarks}

B. optanias was described from New South Wales, Australia; it is known from Java, Tahiti, the Caroline Islands, the southern Mariana Islands, Rapa, northern New Guinea, the Vogelkop Peninsula, Sorong, Arfak Mts, and Ajamaru (ClARKE 1976).

\section{Bactra blepharopis MEYRICK, 1911}

\section{Material examined}

Two males and one female from Viti Levu, Suva, VI. 1974, H.S. RoBINSON and VIII. 1974, no collector. GS 33881, 33920, 33954.

\section{Remarks}

B. blepharopis was described from Queensland, Australia.

\section{Enarmoniini}

\section{Diakonoffiana argynnis RAZOWSKI, MS}

\section{Material examined}

Four females from Viti Levu, Suva Or., Savura Creek, H.S. RoBINSON; GS 33867 - 33869.

\section{Remarks}

This species was described from New Caledonia (RAZOWSKI 2013). The male is unknown. 


\section{Helictophanes saccifera sp. $\mathbf{n}$.}

(Figs 11, 37)

\section{Diagnosis}

In facies, $H$. saccifera is somewhat similar to H. uberana MeYRICK, 1881 from Australia and $H$. alcimofascia RAzowsKI, 2016 from New Caledonia, but $H$. saccifera has purple rust costal forewing markings. The male genitalia of saccifera have a long sack from the caudal edge of the cucullus which in H. uberana is broad and rudimentary, and in H. argillacea (ClARKE, 1976) from Micronesia is subtriangular.

\section{Description}

Wing span $14 \mathrm{~mm}$. Head whitish, labial palpus tinged grey laterally; thorax suffused blackbrown medially. Forewing slightly expanding terminad; costa straight to $3 / 5$; termen somewhat oblique, almost straight. Ground colour whitish, preserved in costal part of basal area and before end subcostally; suffused pale rust along costa with grey in dorsal area. Markings purple rust in costal area, blackish in dorsal part. Cilia (rubbed) paler than markings in costal area. Hindwing brownish; cilia dirty cream.

Variation. Ground colour of forewing of paratype brownish cream, markings rust, preserved in costal area.

Male genitalia (Fig. 11). Uncus vestigial; gnathos arms slender, long; pedunculi long, slender with large scent organ ventrally; sacculus convex; ventral incision deep; ventral lobe of cucullus triangular with small thorn; elongate sack from caudal edge of cucullus; aedeagus fairly short; group of moderately short cornuti in vesica.

Female unknown.

\section{Material examined}

Holotype male: "Fiji: Viti Levu, Nandarivatu, 3-5. IX. 1974", GS 33934. Paratype an identically labelled male, GS 33935.

\section{Etymology}

The name refers to presence of the sack from the caudal part of the cucullus; Lain: saccus a bag and fero - I carry. 


\section{Loboschiza oxybela sp. $\mathrm{n}$.}

(Figs 12, 38)

\section{Diagnosis}

L. oxybela is related to the Australian L. delomilta (TURNER, 1946) but oxybela has a large, triangular ventral lobe of the cucullus, a shorter aedeagus, and a brownish cream forewing ground colour.

\section{Description}

Wing span $8 \mathrm{~mm}$. Head cream, labial palpus and thorax yellow-brown, collar cream rust. Forewing broadest medially; apex rounded; termen convex. Ground colour cream sprinkled and finely strigulated brownish; costal strigulae white, divisions brownish and dark brown; basal part of costa dark brown; some longitudinal small lines in posterior part of wing. Markings dorsal, brownish in form of triangular diffuse basal and subtornal blotches. Cilia pale yellow rust, basal line dark brown. Hindwing brownish, cilia whitish, more brown in anal area.

Variation. Proximal third of thorax more or less mixed brown. Dorsum of forewing suffused brownish grey; basal part of costa yellow brown; markings occasionally dark.

Male genitalia (Fig. 12). Uncus small, short; socii elongate, lateral; arms of gnathos slender; neck of valva long, ventral incision shallow; ventral lobe of cucullus broad, triangular, with apical thorn; caulis long; aedeagus fairly short, simple, weakly tapering terminad.

Female unknown.

\section{Material examined}

Holotype male: "Fiji, Vanua Levu, Savusavy, 28-30. III. 1975"; not dissected. Paratypes three males one labelled as above, two from Viti Levu, Suva, VII. 1974, GS 33941; and Viti Levu, Nandarivatu, 3-5.IX. 1974, GS 33946.

\section{Etymology}

The specific name refers to the termination of the ventral lobe of the cucullus; Greek: oxybeles - pointed.

\section{Procoronis swinhoeiana (WALSINGHAM, 1890)}

\section{Material examined}

Five specimens (3 males, 2 females) from Viti Levu, Savura Creek, 20. VIII. 1974; Vanua Levu, Nuivunda Forest Area, 10-12. IX. 1975, both coll. G.S. RoBINSON; and Fiji, H.S. ROBINSON. GS 15607, 33905-33907. 


\section{Remarks}

P. swinhoeiana was described from Burma (Myanmar) and its synonym, P. rhotias MEYRICK, 1911 from the Moluccas, Indonesia. It also is known also from New Guinea and New Caledonia.

\section{Helictophanes prospera (MEYRICK, 1909)}

\section{Material examined}

One female from Viti Levu, Suva, IV. 1974, H.S. RoBINSON; GS 33951.

\section{Remarks}

In the examined specimen the blades of the signa are shorter than in other specimens, e.g. in the Australian specimen illustrated by HORAK (2006).

Eucosmini

\section{Epinotia prepuncus sp. n.}

(Figs 13, 39)

\section{Diagnosis}

Epinotia prepuncus is closely related to E. canthonias (MEYRICK, 1920) from Bengal, but prepuncus has a black spot at the forewing apex, a bifurcate uncus, and no spines on the neck of the valva.

\section{Description}

Wing span $9 \mathrm{~mm}$. Head and thorax brownish. Forewing slightly expanding terminally; costa weakly convex; termen rather straight, moderately oblique. Ground colour pale brownish sprinkled brown; costal strigulae concolorous with latter except for two subapical which are white; divisions brown. Markings brownish; posterior edge of postbasal fascia and proximal edge of median fascia almost straight; two oblique lines in posterior third of wing; black spot at apex. Cilia brownish grey. Hindwing grey, cilia similar.

Male genitalia (Fig. 13). Uncus broad to middle, bifurcate posteriorly; socius large, tapering terminad; henion absent; valva moderately broad with small neck devoid of spines; sacculus convex posteriorly; cucullus elongate-oval with strong marginal, ventral spines; aedeagus almost uniformly broad throughout.

Female unknown. 


\section{Material examined}

Holotype male: "Fiji: Viti Levu Suva, July 1974; G.S. RoBINSON"; GS 33962. Paratype male, same locality, June 1974, H.S. ROBINSON; GS 33958.

\section{Remarks}

DIAKONOFF (1982) transferred Acroclita canthonias to Epinotia. In describing E. prepuncus in Epinotia, I am following the interpretation of the generic position of $E$. canthonias, a very closely related species, despite the fact that these species lack a henion, which is an important character of Epinotia.

\section{Daedaluncus gen. n.}

Type-species: Daedaluncus fijiensis sp. $\mathrm{n}$.

\section{Diagnosis}

In facies, Daedaluncus is similar to representatives of Epinotia; but the male lacks a costal fold, and the male genitalia resemble those of Peridaedala MEYRICK, 1925 in having a very large complex uncus (?fused with top of the tegumen) but with a pair of apical processes, an ill-defined basal cavity, and a caudally produced cucullus armoured with strong spines. The female genitalia are characterized by a broad, submembranous, scobinate sterigma.

\section{Description}

Venation. In male forewing R5 to just beyond apex near distal end of M1, M2 approaching M1 terminally, base of $\mathrm{CuA} 2$ somewhat opposite base of R1; chorda ill-defined, M-stem rudimentary. In hindwing Rs-M1 stalked to $1 / 3$, M2 approaching M2 basally. In female forewing M1-M2 weakly approaching distally.

Male genitalia. Tegumen elongate; pedunculi long, slender; large structure on top of tegumen with lateral, broad socii and pair of apical sharp processes; valva elongate, broad to middle; neck simple, moderately broad; cucullus proportionally small extending dorsocaudally, with strong spines; sacculus half the length of valva, extending ventroposteriorly, hairy and setose in distal half; aedeagus broad; ca. 15 cornuti in vesica.

Female genitalia. Ovipositor short; apophyses very slender; sterigma broad, submembranous, transversely folded and densely finely spines; distal half of ductus bursae slender; basal part broad with large cingulum; two equally sized signa present. 


\section{Distribution and biology}

Daedaluncus is a monotypical genus known only from Fiji; nothing is known of the biology except the dates of collection of the types: August and November.

\section{Etymology}

The generic name refers to the shape of the uncus; Greek: daidalos - artful.

\section{Daedaluncus fijiensis sp. $\mathbf{n}$.}

(Figs 14, 25, 40)

\section{Diagnosis}

D. fijiensis is the only representative of the genus; of all the Peridaedala spp. (especially $P$. dendrochlora DiAKONOFF, 1967 from the Philippine Islands) it differs in the fine lineation (striations?) and brown costal part of the forewing.

\section{Description}

Wing span $10.5 \mathrm{~mm}$. Head green, thorax darker. Forewing rather uniformly broad throughout; costa weakly convex; termen slightly concave beneath apex, weekly oblique. Ground colour green with a yellowish brown line; costal strigulae brownish cream, divisions brown; costal half of wing suffused and marked yellow-brown; black stripe from apex of wing. Cilia yellowish brown. Hindwing pale brown; cilia cream.

Variation. Female with white costal strigulae before middle and greyer cilia.

Male genitalia (Fig. 14) as described for the genus.

Female genitalia (Fig. 25) as described for the genus.

\section{Material examined}

Holotype male: "Fiji: Viti Levu, Suva, November 1974; H.S. RoBINSON"; GS 33966. Paratype female, similar label but from Viti Levu Suva Creek, 20. VIII. 1974; G.S. RoBINSON; GS 33967.

\section{Etymology}

The name refers to the country of origin. 

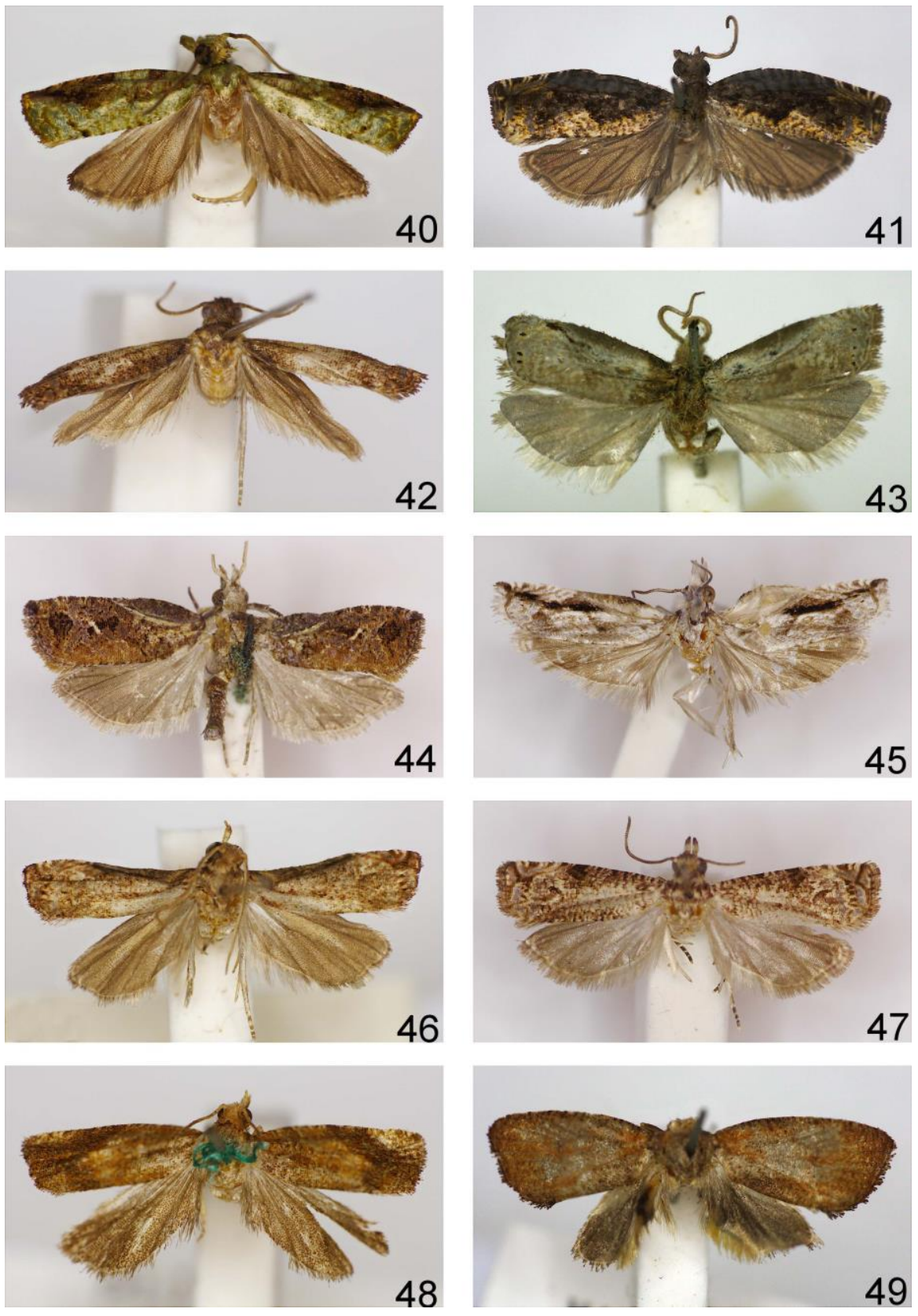

Figs 40-49. Adults. 40 - Daedaluncus fijiensis sp. n., holotype; 41 - Coenobiodes vitiae sp. n., holotype; 42 - Tritopterna rakiraki sp. n., holotype; 43 - Spilonota oligospima sp. n., holotype; 44 - Strepsicrates rotundata sp. n., paratype; 45 - Eccoptocera platamon sp. n., paratype, GS 33961; 46 - Herpystis sunia sp. n., holotype, 47 - Herpystis sunia sp. n., paratype; 48 - Herpystis spinoa sp. n., holotype; 49 - Cryptophlebia ferrugula sp. n., holotype. 


\section{Crocidosema plebejana ZELLER, 1847}

\section{Material examined}

Eight specimens from Wakaya I., 13-15. VIII. 1974, and Viti Levu, Suva, VII and XII. 1974, all coll. G.S. RoBINSON; GS 33891-33896.

\section{Cenobiodes vitiae sp. $\mathbf{n}$.}

(Figs 15, 26, 41)

\section{Diagnosis}

C. vitiae is related to C. melanocosma (TURNER, 1916) from Queensland, Australia as the shape of the valva and wing venation show. The socii, valve and the female genitalia resemble those of an unnamed Australian species (HORAK, 2006: Figs. 660, 664). C. vitiae is distinguished from all congeners chiefly by the presence of a small, bifid sclerite of the uncus (C. acceptana KUZNETZOV, 1973 also has a bifid uncus).

\section{Descriptions}

Wing span $16 \mathrm{~mm}$. Head and thorax brown. Forewing not expanding terminally; costa bent near middle at the end of fold; termen slightly concave beneath apex, not oblique. Ground colour cream, indistinctly tinged brown, preserved in dorsal part of wing, finely strigulated brown. Remaining area brown with some paler and greyer places, strigulated dark brown; costal strigulae whitish cream, divisions brown; ocellus cream. Markings dark brown, indistinct, diffuse. Cilia brownish, cream at tornus. Hindwing including cilia brownish.

Variation. Female forewing ground colour whitish with brown suffusions; markings brown, in dorsal area better developed than in male.

Male genitalia (Fig. 15). Uncus a helmet-shaped lobe with small, bifid, sclerotized process; socius long, slender; neck of valva fairly broad, densely hairy beyond basal cavity; cucullus oval with well-developed ventral lobe; aedeagus simple, broad; cornuti numerous, forming a cluster.

Female genitalia (Fig. 26). Papilla analis proportionally small; apophyses short; sterigma plate-shaped forming three small distal prominences; cingulum large, anterior; two strong signa present.

\section{Material examined}

Holotype male: "Fiji: Viti Levu Nandarivatu, 20-26. V. 1934, H.W. SIMMONDS; B.M.1954495"; GS 33865. Paratypes three females from same locality, dated 3-5.IX. 1974, G.S. RoBINSON; GS 33864, 33866. 


\section{Herpystostena sicaria (DIAKONOFF, 1982)}

\section{Material examined}

One male from Suva (27. I. 1941, R.A. LEVER; GS 338750.

\section{Remarks}

H. sicaria was described from Sri Lanka from a single male; it was also recorded from East Sumba by DIAKONOFF (1984). The Fiji specimen differs slightly from the holotype in having more distanced saccular spines and an additional smaller ventral spine in the setose part of the cucullus. The female remains unknown.

\section{Tritopterna eocnephaea (MEYRICK, 1935)}

\section{Material examined}

One female from Wakaya Island, 13-14. IV. 1974, H.S. RoBINSON, GS 33877.

\section{Remarks}

T. eocnephaea is known from the Marquesas Islands (CLARKE 1986); it was described from Hiva Oa and its synonym, T. galena CLARKE, 1971 from Rapa Island.

\section{Tritopterna rakiraki sp. $\mathbf{n}$.}

(Figs 16, 42)

\section{Diagnosis}

T. rakiraki is related to T. eocnephaea, but rakiraki has a longer uncus distinctly bifurcate terminally, a short neck of the valva and a broader proximal part of the aedeagus.

\section{Description}

Wing span $8 \mathrm{~mm}$. Head and thorax greyish brown. Forewing broadest submedially; costa weakly convex, slightly concave beneath apex. Forewing brownish; costal strigulae creamish, indistinct; divisions brown; ocellus ill-defined, brownish grey; pinkish strigulae at termen; two blackish marks before apex and near termen, postmedially. Cilia brownish. Hindwing brownish grey, cilia paler.

Male genitalia (Fig. 16). Uncus large, slender, bifid terminally; socius rudimentary; valva broad basally; neck elongate, setose along middle; cucullus oval with short but distinct ventral lobe; aedeagus proportionally short, broad anteriorly. 
Female unknown.

\section{Material examined}

Holotype male: "Fiji: Viti Levu, Rakiraki, 12. XI. 1973; T.H. \& H. HowARTH, B.M. 1973598"; GS 33942.

\section{Etymology}

The specific epithet refers to the type locality.

\section{Heleanna physalodes (MEYRICK, 1910)}

\section{Material examined}

One female from Suva Peninsula (VI. 1956, H.S. EvAns; GS 33876).

\section{Remarks}

H. physalodes was described from the Chagos Islands (I. du Coin); according to ClaRKE (1976), it is also known from the Seychelles, India, Ceylon, Solomon Islands, Austral Islands, Fiji and Southern Mariana.

\section{Spilonota oligospina sp. $\mathbf{n}$.}

(Figs 17, 43)

\section{Diagnosis}

In $S$. oligospina the socii and cucullus are similar to those of $S$. granlacia RAZOWSKI, 2013 from New Caledonia, but the latter has a very long aedeagus and uncus. The uncus of $S$. oligospina is very short, the ventral thorn of the cucullus is small and the caudal cucullar spines are strong.

\section{Description}

Wing span ?? Head cream slightly tinged brown, thorax grey. Forewing slender; costa straight with large costal fold; termen straight, oblique. Ground colour grey-white, strongly mixed and suffused grey and brownish; costal strigulae whitish, indistinct; a few brownish grey spots present. Markings reduced to indistinct brown-grey spot near middle subdorsally. Cilia grey. Hindwing grey; cilia whitish.

Variation. Forewing of paratype paler than that of holotype, more brownish cream distally, without markings. 
Male genitalia (Fig. 17). Uncus short, rounded; basal part of socius broad, distal half slender, long; basal part of valva broad, ventral incision shallow, neck slender; cucullus rather small with three distinct caudal spines and small spine at top of ventral lobe; aedeagus shorter than sacculus, rather slender.

Female unknown.

\section{Material examined}

Holotype male: "Fiji: Taveuni,, 23-29. VI. 1951, H.W. SimMONDS; B.M.19154-266"; GS 33950. Paratype male from Viti Levu, Nandarivatu, IX. 1955, H.W. SIMMONDS; GS 33949.

\section{Etymology}

The name refers to the number of spines of the cucullus; Greek: oligos - not numerous, Latin: spina - a spine.

\section{Strepsicrates rotundata $\mathbf{s p .} \mathbf{n}$.}

(Figs 18, 44)

\section{Diagnosis}

S. rotundata is related to $S$. holotephras (MEYRICK, 1924) from Lautoka, Fiji, but is distinct in the cucullus having a broad, rounded ventral lobe.

\section{Description}

Wing span $20 \mathrm{~mm}$. Head and thorax brown; tegula paler posteriorly. Forewing not expanding terminally; costa straight beyond end of fold which almost reaches its middle; termen not oblique, almost straight. Ground colour pale brown with some rust parts; strigulation brown; costal strigulae fine, cream, divisions brown; brown spot at disc followed by white stripe. Markings brown in form of postbasal blotch divided into spots, remnant of median marking, subterminal blotch connected to apical spot and paler, indistinct tornal spot. Cilia brownish. Hindwing pale brown, cilia similar.

Variation. Two paratypes with forewing ground colour more grey than in holotype. Markings more or less distinct.

Male genitalia (Fig. 18). Top of tegumen convex; uncus in form of pair of sublateral processes; socius weak; sacculus convex; neck of valva short; cucullus moderate with broad, rounded ventral lobe; pollex distinct; aedeagus broad, tapering terminally.

Female unknown. 


\section{Material examined}

Holotype male: "Fiji: Viti Levu, Nandarivatu, IX. 1955, H.W. SIMMONDS, B.M. 1955391"; not dissected. Paratypes 4 identically labelled males, one with genitalia on slide 33961.

\section{Etymology}

The specific name refers to the shape of ventral lobe of cucullus; Latin: rotundata rounded.

\section{Strepsicrates poliophora BRADLEY, 1962}

\section{Material examined}

One male from Vanua Levu, Forest Area Niuvudi, 3-6. IX. 1975, P.A. MAdDISON, GS 33872 .

\section{Remarks}

This species was described from the New Hebrides and recorded from Nairavaya, Fiji by RAZOWSKI (2016).

\section{Eccoptocera platamon sp. $\mathbf{n}$.}

(Figs 19, 27, 45)

\section{Diagnosis}

E. platamon is related to E. bidolon RAZOWSKI, 2016 from the vicinity of Lami, Fiji as the shapes of the signa and process of the subgenital sternite show. The male genitalia of $E$. platamon resemble those of E. foetivorans (BUTLER, 1881) from Oahu, Hawaiian Islands, but the latter has a longer ventral tip of the aedeagus, a shorter uncus and a much smaller basal plate of the ventral signum. In facies E. platamon is distinct from the two other species primarily in having a rather slender grey forewing with blackish markings.

\section{Description}

Wing span $17 \mathrm{~mm}$. Head and thorax greyish; labial palpus and vertex mixed brownish, tegula brownish posteriorly. Forewing not expanding terminad; costa slightly concave postmedially, costal fold to beyond middle, brownish and grey; termen gently concave beneath apex. Ground colour whitish with brownish suffusions and diffuse lines; costal strigulae white, divisions brownish; ocellus weakly developed. Markings brownish: postbasal fascia preserved in dorsal area of wing connected to incomplete median fascia which is marked black, similarly 
to posterior parts of markings at apex; tornal blotch brownish grey. Cilia white with brownish grey scaling, black at apex. Hindwing brownish, cilia more cream.

Variation. Ground colour of female forewing whitish, suffusions indistinct, brown; costal strigulae and ocellus well developed. Markings brown. Other specimens more or less brownish.

Male genitalia (Fig. 19). Uncus long, expanding terminally with indistinct apical concavity; socius moderately large, well sclerotized in outer half dorsally; neck of valva tapering posterad; cucullus with large proximal lobe and strong pollex; more than 20 cornuti in vesica.

Female genitalia (Fig. 27). Sterigma broad, expanding posterad, fused with subgenital sternite which has a long, slender median process; posterior sclerite of ductus bursae shorter than cingulum; dorsal signum broad with small basal plate, the ventral with very large basal sclerite reaching base of ductus bursae.

\section{Material examined}

Holotype male: “Fiji, Nandarivatu 15-17. VIII. 1969, H.S. \& G.S. RoBINSON”; GS 33965. Paratypes 3 males and 2 females labelled: "Fiji: Viti Levu Nandarivatu, IX.1955, H.W. SIMMONDS, B.M.1955-391" one with GS 33963 and with similar label dated 3-5.IX. 1974.

\section{Etymology}

The specific name refers to large basal plate of the signum; Greek: platamon - something flat.

\section{Eccoptocera ?bidolon RAZOWSKI, 2016}

\section{Material examined}

Twenty-seven specimens from Viti Levu (3-5. IX. 1974; GS 33958, 33968 - 33970), Viti Levu Suva (IV, VII, IX. 1974; GS 33855 - 33857, 33857); two males and two females from Viti Levu Nandarivatu (3-5. IX. 1974; GS 33958, 33968 - 33970) and Vanua Levu.

In facies the specimens are very similar to the holotype, but they exhibit considerable variation. Ground colour white, more or less distinctly strigulated grey-black, with dorsobasal blotch or with blackish dorsum. Female genitalia as in holotype. Male genitalia as described for Eccoptocera sp. (RAZOWSKI, 2016). Other specimens with greyish or brownish forewing ground colour, often without transverse strigulation and with variable markings. All these specimens are probably conspecific with the holotype of E. bidolon.

Eccoptocera form. To this form belong specimens with male and female genitalia almost identical with the type but with the process of the subgenital sternite longer and slenderer. These are specimens from Viti Levu Suva, Nandarivatu, and Viti Levu Suvra Creek. 


\section{Herpystis sunia sp. n.}

(Figs 20, 28, 46, 47)

\section{Diagnosis}

H. sunia is related to the Indian H. tinctoria MEYRICK, 1916, but sunia has a quite different cucullus, which has an oblique caudal edge.

\section{Description}

Wing span $10.5 \mathrm{~mm}$. Head and thorax brownish. Forewing slighty expanding terminally; costa straight to $2 / 3$ (end of fold), termen not oblique. Ground colour brownish cream sprinkled brownish and rust, in distal part slightly suffused brownish; costal fold blackish brown; costal strigulae whitish, divisions brown; ocellus brownish cream. Cilia (damaged) brownish. Hindwing brownish, cilia similar.

Variation. Females (wing span 11-14 mm). Forewing ground colour cream more or less strongly strigulated brown; ocellus cream with brown dots; remnants of markings brown.

Male genitalia (Fig. 20). Tegumen pointed apically; socius small; valva slender, concave near middle ventrally; cucullus slender with oblique, convex caudal edge and small pollex; aedeagus long, slender, uniformly curved dorsally; cornuti numerous slender spines.

Female genitalia (Fig. 28). Sterigma ill-defined, membranous; antrum broad, weakly sclerotized extending proximally into weakly sclerotized tube; long, curved sclerite from middle to base of ductus bursae; ductus seminalis and bulla large; two signa with long blades.

\section{Material examined}

Holotype male: "Fiji: Viti Levu, Suva, February 1975"; GS 33937; paratypes three similarly labelled females dated January and February 1975 and July 1974, one with GS 33936

\section{Herpystis spinoa sp. $\mathbf{n}$.}

(Figs 21, 48)

\section{Diagnosis}

$H$. spinosa is similar and related to $H$. sunia; the two lack a ventral convexity of the sacculus and a horizontal position of the cucullus. H. spinoa is distinguished chiefly by the presence of a series of saccular spines that are lacking in sunia. 


\title{
Description
}

Wing span $11 \mathrm{~mm}$. Head and thorax cream brown, labial palpus paler. Forewing not expanding terminad; costa slightly bent to middle then straight; termen weakly oblique. Ground colour cream, reticulate brownish and ferruginous, suffused brown in dorsal area and with blackish brown from wing apex to before tornus. Costal strigulae fine, whitish, divisions brownish. Cilia damaged. Hindwing brown, remnants of cilia similar.

Male genitalia (Fig. 21). Top of tegumen rounded; socius rather slender, long; valva slender with indistinct neck; sacculus slightly concave near middle with four spines before cucullus; latter elongate, rounded caudally with oblique ventroanterior row of setae; pollex (?) indistinct, small convexity armoured with small spine; aedeagus uniformly broad.

Female unknown.

\section{Material examined}

Holotype male: “Fiji, Viti Levu, Suva /Apr./ 1974, H.S. RoBINSON”; GS 33955.

\section{Icelita grossoperas RAZOWSKI, 2016}

\section{Material examined}

One male from Labasa, Vanua Levu, 30/I/75, P.A. MADDISON, M.V. LIGHT; GS 33874.

\section{Remarks}

This species was described from the vicinity of Lami, Fiji on the basis of one male. The present specimen differs slightly from the holotype in having a deeper apical incision of the tegumen. In facies, a female (Viti Levu, Suva or, Savura Creek; H.S. Robinson, Fiji 1966/67, GS 33945) does not differ from the examined male, but its genitalia are very similar to those of I. tatarana coppelia ClARKE, 1976 from Southern Mariana Islands, thus the identification is uncertain.

\author{
Grapholitini
}

\section{Thaumatotibia zophophanes (TURNER, 1946)}

\section{Material examined}

One male from Wakaya Island, 13-15. VII. 1974, G.S. RoBINSON; GS 33932. 


\section{Remarks}

T. zophophanes was described from Queensland, Australia.

\section{Thaumatotibia chaomorpha (MEYRICK, 1928)}

\section{Material examined}

Two males from Viti Levu Suva, July 1974 (GS 33972) and Viti Levu Savusavu, 5-8. VIII. 1974, GS 33973, both collected by G.S. ROBINSON.

\section{Remarks}

T. chaomorpha was described from the Marquesas.

\section{Cryptophlebia ferrugulla sp. $\mathbf{n}$.}

(Figs 22, 49)

\section{Diagnosis}

C. ferrugulla is related to C. omphala RAzowsKi, 2013 from New Caledonia, but $C$. ferrugulla has distinct lateroterminal lobes of the tegumen and four strong ventral spines of the cucullus.

\section{Description}

Wing span $15 \mathrm{~mm}$. Head and thorax pale rust. Hindleg with brownish scales of scent organ. Forewing expanding terminally; costa somewhat convex; termen slightly oblique, straight. Wing nearly unicolorous pale ferruginous delicately strigulated browner. Cilia brownish ferruginous. Hindwing pale brownish grey with anal scent organ; cilia much creamer.

Variation. Forewing browner than in holotype, with more or less distinct strigulation.

Male genitalia (Fig. 22). Terminal part of tegumen forming two lateral lobes; neck of valva weak; cucullus with two anterior and three posterior strong spines; aedeagus slender, broadening basally.

\section{Material examined}

Holotype male: "Fiji, Viti Levu, Suva, /Apr. 1974, G.S. RoBINSON"; GS 33926. Paratypes a pair labelled as above and two males from same locality but dated December 1974 and February 1975. 


\section{Cryptophlebia amblyopa CLARKE, 1976}

\section{Material examined}

Six males and five females from Viti Levu Suva dated January 1975, August 1974 and September 1974, all coll. G.S. RoBINSON, GS 33924, 33925, 33927, 33928, 33930, 1931.

\section{Remarks}

This species was described from Palau, Micronesia.

Acanthoclita defensa (MEYRICK, 1922)

(Fig. 29)

\section{Description}

Female genitalia (Fig. 29). Sterigma rounded proximally, almost straight distally; antrum edged by a distinct sclerite; ductus bursae slender with subterminal, posterior sclerite; ductus seminalis extending from postbasal part of the former; signa large, broadening terminally.

\section{Material examined}

Five females from Viti Levu Suva, III, V, and VI, coll. H.S. RoBINSON and from Wakaya Island, 13-15. VIII. 1974, coll. G.S. RoBINSON; GS 33898, 33899, 33900-33902, 33904.

\section{Remarks}

A. defensa was described from both sexes from the vicinity of Lami. The female lectotype, selected from four co-types, was illustrated by CLARKE (1958). The examined specimens fit the illustration well except for the signum, which is not clear in the illustration, hence it is redescribed here.

Another closely-related species is A. iridorphna MEYRICK, 1936 from Taiwan, also illustrated by CLARKE (1958), which may prove to be conspecific. The Australian $A$. trichograpta (MEYRICK, 1911) differs from A. defensa chiefly in its short aedeagus and slender signa.

\section{Cydia expulsa RAZOWSKI, 2016}

\section{Material examined}

Two males from Viti Levu Nandarivatu, 3-5. IX. 1974, G.S. RoBINSON, GS 33878; and similar label with additional data: Forest Area, NW of Mbutha Bay, GS 33933. 


\title{
Remarks
}

C. expulsa was described from Nairayawa. The male genitalia are similar to Pammene critica (MEYRICK, 1905) described from Bengal, India and illustrated by DIAKONOFF (1982), but expulsa lacks abdominal scent organs and a subtriangular cucullus. The genitalia of expulsa also are similar to another Indian species, Cydia conciliata (MEYRICK, 1920), illustrated by CLARKE (1958), but those of expulsa have a shorter neck of the valva and has a longer proximal edge of the cucullus; the species are quite different externally.

\section{Grapholita trossula RAZOWSKI, 2016}

\author{
Material examined \\ One male from Viti Levu Tholoisuva, 18. I. 1975, G.S. RoBINSON; GS 33952.
}

\section{Remarks}

G. trossula was described from the vicinity of Lami, Fiji.

\section{Microsarotis sanderyi KOMAI \& HORAK, 2006}

\section{Material examined}

Four males and four females from Vanua Levu, Nuivunda Forest Area, NW of Mbutha Bay, 10-12. IX. 1975, H.S. RoBINSON; GS 3938-3940.

\section{Remarks}

M. sanderyi was described from northern Queensland, Australia. The Fiji specimens have a brown head and thorax with a more or less distinct bluish silvery shine, and often lack the black basal line of the termen, which was identified as the diagnostic feature.

\section{REFERENCES}

Clarke J.F.G. 1958. Catalogue of the type specimens of Microlepidoptera in the British Museum (Natural History) described by Edward MeYrick. Vol. III. British Museum (Natural History), London.

Clarke J.F.G. 1976. Microlepidoptera: Tortricoidea. Insects of Micronesia 9(1): 1-144.

Clarke J.F.G. 1986. Pyralidae and Microlepidoptera of the Marquesas Archipelago. Smithsonian Contribution to Zoology 416: 1-485. 
DiAKonoff A. 1982. On a collection of some families of Microlepidoptera from Sri Lanka (Ceylon). Zoologische Verhandelingen 193: 1-124, 18 pls.

DiAKonofF A. 1984. Wissenschaftliche Ergebnisse der Sumba-Expedition des Museums für Völkerkunde und des Naturhistorischen Museums in Basel, 1949. Microlepidoptera. Part 3. Entomologica Basiliensia 9: 373-431.

HoRAK M. 2006. Olethreutinae moths of Australia (Lepidoptera: Tortricidae. Monographs on Australian Lepidoptera 10. CSIRO, Canberra.

RAZOWSKi J. 2013. Leaf-rollers from New Caledonia (Lepidoptera: Tortricidae). SHILAP Revista de Lepidopterologia 41(161): 69-93.

RAzowski J. 2016 (in press). Tortricidae (Lepidoptera) from the Fiji Islands. Acta zoologica cracoviensia.

Received: 22 October 2015

Accepted: 10 November 2015 